Raine AF, Sowter DJ, Brown AF, Sutherland WJ. 2006. Migration patterns of two populations of twite Carduelis flavirostris in Britain. Ringing \& Migration. 23:45-52.

Robinson RA, Kew JJ, Kew AJ. 2010. Survival of suburban blackbirds Turdus merula varies seasonally but not by sex. Journal of Avian Biology. 41:83-87.

Siriwardena GM. 2010. The importance of spatial and temporal scale for agri-environment scheme delivery. Ibis. 152:515-529.

Smith WA. 1968. The Band-tailed Pigeon in California. California Fish and Game. 54:4-16.
Wolf C, Riffel M, Weyman G, Douglas M, Norman S. 2010. Telemetry-based field studies for assessment of acute and short-term risk to birds from spray applications of chlorpyrifos. Environmental Toxicology and Chemistry. 29:1795-1803.

Woodin MC, Skoruppa MK, Edwardson JW, Austin JE. 2012. Evaluation of capture techniques for Long-billed Curlews wintering in Texas. Bulletin of the Texas Ornithological Society. 45:12-22.

Wooten WA. 1955. A trapping technique for Band-tailed Pigeons. Journal of Wildlife Management. 19:411-412.

The Wilson Journal of Ornithology 130(1):326-334, 2018

\title{
A simplified field protocol for genetic sampling of birds using buccal swabs
}

\author{
Julia T. Vilstrup, ${ }^{1,2}$ Thomas D. Mullins, ${ }^{1}$ Mark P. Miller, ${ }^{1}$ Will McDearman, ${ }^{3}$ Jeffrey R. Walters ${ }^{4}$ and \\ Susan M. Haig ${ }^{1 *}$
}

ABSTRACT - DNA sampling is an essential prerequisite for conducting population genetic studies. For many years, blood sampling has been the preferred method for obtaining DNA in birds because of their nucleated red blood cells. Nonetheless, use of buccal swabs has been gaining favor because they are less invasive yet still yield adequate amounts of DNA for amplifying mitochondrial and nuclear markers; however, buccal swab protocols often include steps (e.g., extended air-drying and storage under frozen conditions) not easily adapted to field settings. Furthermore, commercial extraction kits and swabs for buccal sampling can be expensive for large population studies. We therefore developed an efficient, cost-effective, and field-friendly protocol for sampling wild birds after comparing DNA yield among 3 inexpensive buccal swab types ( 2 with foam tips and 1 with a cotton tip). Extraction and amplification success was high $(100 \%$ and $97.2 \%$ respectively) using inexpensive generic swabs. We found foam-tipped swabs provided higher DNA yields than cottontipped swabs. We further determined that omitting a drying step and storing swabs in Longmire buffer increased efficiency in the field while still yielding sufficient amounts of DNA for detailed population genetic studies using mitochondrial and nuclear markers. This new field protocol allows time- and cost-effective DNA sampling of juveniles or small-bodied birds for which drawing blood

\footnotetext{
${ }^{1}$ US Geological Survey, Forest and Rangeland Ecosystem Science Center, Corvallis, OR, USA.

2 Department of Fisheries and Wildlife, Oregon State University, Corvallis, OR, USA.

${ }^{3}$ Division of Restoration and Recovery, US Fish and Wildlife Service, Jackson, MS, USA.

${ }^{4}$ Department of Biological Sciences, Virginia Tech, Blacksburg, VA, USA.

* Corresponding author: susan_haig@usgs.gov
}

may cause excessive stress to birds and technicians alike. Received 28 June 2016. Accepted 4 January 2017.

Key words: birds, buccal swab, DNA, field sampling, Leuconotopicus borealis, population genetics, Redcockaded Woodpecker.

\section{Un protocolo de campo simplificado para la toma de muestras genéticas de aves usando raspados bucales}

RESUMEN (Spanish)_El muestreo de DNA es un prerrequisito esencial para el desarrollo de estudios de genética de poblaciones. Por muchos años, la obtención de muestras de sangre fue el método preferido para obtener DNA en aves por sus glóbulos rojos nucleados. Sin embargo, la obtención de raspados bucales ha ganado adeptos porque son menos invasivos y permiten la obtención de cantidades adecuadas de DNA para amplificar marcadores mitocondriales y nucleares. Los protocolos de raspados bucales ocasionalmente incluyen pasos (como el secado al aire y almacenamiento en condiciones de congelación) que no se adaptan fácilmente a condiciones de campo. Además, los kits comerciales de extracción y los hisopos para muestreo bucal pueden ser caros para el caso de estudios poblacionales grandes. Por ello, desarrollamos un protocolo eficiente, de bajo costo y que se acomoda a condiciones de campo para el muestreo de aves silvestres, después de comparar la cantidad de DNA de tres tipos de hisopos bucales baratos (dos con puntas de esponja y uno con punta de algodón). El éxito en la extracción y amplificación fue alto ( $100 \%$ y $97.2 \%$ respectivamente) usando hisopos genéricos baratos. Encontramos que los hisopos con punta de esponja proveen cantidades mayores de DNA que los de punta de algodón. Además determinamos que omitir el paso de secado y almacenar los hisopos en buffer de Longmire incrementaron su eficiencia en el campo mientras mantenían producían cantidades suficientes de DNA para estudios genéticos usando marcadores mitocondriales y genéticos. Este nuevo protocolo permite el muestreo de DNA eficiente en tiempo y costo para juveniles o aves de tamaño pequeño en las cuales la toma de 
muestras de sangre puede causar un estrés excesivo para las aves y los técnicos de campo.

Palabras clave: aves, DNA, Leuconotopicus borealis, muestreo de campo, raspado bucal.

Molecular data provide crucial information for population biologists, behavioral ecologists, and managers working to conserve species (Haig et al. 2016). Key to success of these analyses is acquisition of sufficient DNA samples to fulfill study needs without harming the individuals being sampled. DNA can be extracted from various tissues (e.g., skin and blood; Müllenbach et al. 1989) but also from non- or less-invasive sources requiring minimal to no animal contact (e.g., hair: Garza and Woodruff 1992, Romain-Bondi et al. 2004; fecal samples: Gerloff et al. 1995, Idaghdour et al. 2003; feathers: Taberlet and Bouvet 1991, Harvey et al. 2006; saliva: Handel et al. 2006, Wellbrock et al. 2012; eggshells: Dai et al. 2015). Non- and less-invasive sampling techniques minimize stress to study organisms and are ideal for small-bodied species or when sampling juveniles.

Buccal swabs are becoming a popular choice for less-invasive sampling because protocols require minimal training to implement and the chances of injuring the bird are low (Table 1). Buccal swabs have been used extensively in laboratory studies of humans (Steinberg et al. 1997, Walker et al. 1999) as well as in several amphibian and reptilian DNA field studies (Pidancier et al. 2003, Poschadel and Moller 2004, Broquet et al. 2006, Miller 2006, Beebee 2007). They have even been used to sample fish (Smalley and Campanella 2005, Campanella and Smalley 2006). Their one drawback, however, is that samples must be treated immediately in the field for a relatively long period, and they are not viable unless stored under freezing conditions.

In avian genetics, blood sampling has been the preferred source for DNA because of the presence of nucleated red blood cells, which provide high yields of DNA (e.g., Haig et al. 1994, Funk et al. 2007). Feathers can also be a good source of DNA; feather shafts provide a microenvironment in which the DNA is protected from degrading conditions, and they have been used successfully for a variety of studies, including genetic structure and phylogeography (De Volo 2008, Rudnick et al.
2008). As in our case, however, nestlings can be a limited source of feathers and are more difficult to bleed, and therefore sampling these tissues may not be practical because they can require extended handling times and dramatically increase stress on the animal.

Buccal swabs are slowly emerging as an alternative to blood sampling in avian population genetic studies (11 published studies; Table 1), although limitations in field protocols have slowed their adoption. For example, a number of commercial buccal swabs and DNA extraction solutions are available (e.g., Epicentre's MasterAmp and Catch-All swabs and QuickExtract DNA extraction solution; Isohelix's DNA Buccal Swabs and Buccal-Prep DNA Isolation Kit), but these kits are primarily designed to sample buccal cells in medical or veterinary settings where immediate laboratory processing is possible. Their protocols often involve air-drying the swab for 10-15 min (e.g., MasterAmp Buccal Swab DNA Extraction Kit protocol, www.epibio.com; GenElute Mammalian Genomic DNA Mini-prep Kit protocol, www.sigmaaldrich.com), which may be impractical when collecting samples in a field setting. If not processed immediately, the swabs can be frozen at $-20{ }^{\circ} \mathrm{C}$ for up to 6 months, but freezing is often not simple in a field setting (although see Handel et al. 2006). An additional drawback, particularly for large field studies, is the cost per individual sample using commercial kits (e.g., Boca Scientific's Isohelix Buccal DNA Isolation Kit with swabs is US\$5-\$11.5 per sample, depending on whether dri-capsules and buccalfix and buccal prep DNA isolation are used also).

Buccal swab applications have potential in the field if current drawbacks associated with some protocols and the cost of commercial kits can be overcome. In this paper, we outline development of a new protocol for sampling and storing avian buccal swab samples in the field. Our approach excludes air-drying steps and instead has technicians place swabs directly into Longmire buffer (Longmire et al. 1992) for ambient storage (suggested by Seki 2003 and Handel et al. 2006). We compared the effectiveness of inexpensive cotton and foam swabs and developed a simplified DNA extraction protocol. Subsequently, we compared extraction success, DNA concentrations, total yield, and amplification success among swab types to optimize our protocol as an inexpensive, 
Table 1. Success of avian studies sampling buccal cells for DNA extraction and amplification.

\begin{tabular}{|c|c|c|c|}
\hline Species & Scientific name & Sampling method & Swab storage \\
\hline Ryukyu Robin (wild) & Larvivora komadori & Cotton swab & $\begin{array}{l}\text { Longmire buffer at RT for } \\
1 \text { week, then } 5^{\circ} \mathrm{C} 1 \text { month }\end{array}$ \\
\hline Greater Sage-Grouse (wild) & $\begin{array}{l}\text { Centrocercus } \\
\text { urophasianus }\end{array}$ & Cotton q-tip & Dry, $-20{ }^{\circ} \mathrm{C}$ \\
\hline 12 different species (wild) & & $\begin{array}{l}\text { Cotton swab } \\
\text { ( } 2 \text { per individual })\end{array}$ & $\begin{array}{l}99.5 \% \text { ethanol, }-20{ }^{\circ} \mathrm{C} \text { for } \\
3 \text { months }\end{array}$ \\
\hline $\begin{array}{l}\text { Black-capped and Boreal } \\
\text { Chickadee (wild) }\end{array}$ & $\begin{array}{l}\text { Poecile hudsonicus } \\
\text { and P. atricapillus }\end{array}$ & $\begin{array}{l}\text { Epicentre's Catch-All } \\
\text { foam swab }\end{array}$ & $\begin{array}{l}\text { Air dried } 10-15 \mathrm{~min}, \mathrm{RT} \\
1-18 \text { months }\end{array}$ \\
\hline $\begin{array}{l}\text { Red-cockaded Woodpecker } \\
\text { (wild) }\end{array}$ & Leuconotopicus borealis & Isohelix swabs & Air dried, then $-20{ }^{\circ} \mathrm{C}$ \\
\hline $\begin{array}{l}\text { Japanese Quail and Screech } \\
\text { Owl (captive) }\end{array}$ & $\begin{array}{l}\text { Coturnix japonica } \\
\text { and Megascops asio }\end{array}$ & Cotton swab & Dry, $-20{ }^{\circ} \mathrm{C}$ \\
\hline Ivory Gull (wild) & Pagophila eburnea & Milian cotton swab & $\begin{array}{l}\text { Air dried } 10-15 \min , 0-10{ }^{\circ} \mathrm{C} \\
\text { with silica gel beads up to } 1 \\
\text { month, then }-20{ }^{\circ} \mathrm{C}\end{array}$ \\
\hline Common Swift (wild) & Apus apus & $\begin{array}{l}\text { Chromatography } \\
\text { paper strip }\end{array}$ & $5 \%$ Chelex 100 \\
\hline Parrots species (captive) & Amazona spp. & Cotton swab & $\mathrm{n} / \mathrm{a}$ \\
\hline Zebra Finch & Taeniopygia guttata & Whatman paper strip & $\begin{array}{l}5 \% \text { Chele } \times 100 \text { at } \mathrm{RT},-20^{\circ} \mathrm{C} \\
\text { up to } 3 \text { years }\end{array}$ \\
\hline
\end{tabular}

$\mathrm{RT}=$ room temperature; SDS = Sodium Dodecyl Sulfate; Prot.K = Proteinase K; STE = Sodium Chloride-Tris-EDTA buffer; Microsats = microsatellites; CR = mitochondrial control region; ${ }^{\mathrm{a}}$ total yield is not specified in publication and therefore calculated from assumed elution volume according to extraction protocol; ${ }^{\mathrm{b}}$ incubation time not specified in protocol so assumed according to manufacturer's manual.

field-friendly alternative to commercial buccal swab kits and blood sampling. We further demonstrate the benefit of using these new protocols by distributing our buccal kits to field crews sampling young Red-cockaded Woodpecker (Picoides borealis, now Leuconotopicus borealis) chicks across the southeastern United States and report on the ease of their use in the field. Redcockaded Woodpeckers are cooperative breeders and one of the first species listed under the US Endangered Species Act because of the loss and degradation of their longleaf pine habitat (USFW 2003, Walters and Garcia 2016).

\section{Methods}

\section{Field sampling}

We compared the DNA yield among 3 generic swabs used to sample Red-cockaded Woodpecker nestlings (5-14 d old) during summer 2014 as part of a larger study investigating population genetic structure in the species. The swabs were composed of either foam on wood ( $n=24$; VWR 82030-594; US $\$ 0.37 / \mathrm{swab})$, cotton on plastic ( $n=24$; Bi-Mart; US\$0.014/swab), or foam on plastic $(n=24$; VWR 82030-716; US $\$ 0.26 / \mathrm{swab})$. The swabs were cut to $\sim 2-4 \mathrm{~cm}$ to fit into a $2 \mathrm{~mL}$ cryogenic tube (Fig. 1) and sent as part of a sampling kit to field crews at 6 sites in the southeastern United States: Vernon unit, Kisatchie National Forest, Louisiana; Three Lakes Wildlife Management Area, Florida; Fort Stewart, Georgia; Fort Bragg, North Carolina; Carolina Sandhills National Wildlife Refuge, South Carolina; and Marine Corps Base Camp Lejeune, North Carolina. Each swab type was sent to 2 locations (foam on wood: Camp Lejeune and Fort Bragg; cotton on plastic: Fort Stewart and Vernon; foam on plastic: Three Lakes and Carolina Sandhills).

We instructed field workers to gently rotate a swab inside the mouth of a nestling for $15 \mathrm{~s}$, taking care to avoid the tongue (Fig. 2). The swab was 
Table 1. Extended.

\begin{tabular}{|c|c|c|c|c|c|}
\hline Extraction method & Average DNA yield & $\begin{array}{c}\text { DNA } \\
\text { per PCR }\end{array}$ & $\begin{array}{c}\text { Amp. } \\
\text { success } \%\end{array}$ & DNA marker & Reference \\
\hline $\begin{array}{l}\text { Phenol/chloroform } 17 \mathrm{~h} \\
\text { incubation }\end{array}$ & $1.3 \pm 0.7 \mu \mathrm{g}$ & $\mathrm{n} / \mathrm{a}$ & $\mathrm{n} / \mathrm{a}$ & Sexing & Seki 2003 \\
\hline $\begin{array}{l}\text { QIAmp DNA Micro kit, } 24 \\
\text { h incub. }\end{array}$ & $41 \mathrm{ng} / \mu \mathrm{L}(4.1 \mu \mathrm{g})^{\mathrm{a}}$ & $123 \mathrm{ng}$ & $\mathrm{n} / \mathrm{a}$ & Sexing & Bush et al. 2005 \\
\hline $\begin{array}{l}\text { Digested in } 10 \% \text { SDS, } \\
\text { Prot.K and STE buffer, } \\
\text { overnight incub. }\end{array}$ & $\mathrm{n} / \mathrm{a}$ & $100 \mathrm{ng}$ & $82.2-98.1$ & Sexing & $\begin{array}{l}\text { Arima and Ohnishi } \\
2006\end{array}$ \\
\hline $\begin{array}{l}\text { BuccalAmp DNA extraction, } \\
46 \text { min incub.; and salt } \\
\text { extraction }\end{array}$ & $\begin{array}{l}4.3 \pm 4.9 \mathrm{ng} / \mu \mathrm{L} \\
(2.2 \mu \mathrm{g}){ }^{\mathrm{a}} \\
2.7 \pm 3.9 \mathrm{ng} / \mu \mathrm{L}\end{array}$ & $\begin{array}{l}1 \mu \mathrm{L} \text { of } \\
\sim 3-4 \mathrm{ng}\end{array}$ & $\mathrm{n} / \mathrm{a}$ & $\begin{array}{l}\text { Sexing, } \\
5 \text { microsats, } \\
\text { CR }\end{array}$ & Handel et al. 2006 \\
\hline $\begin{array}{l}\text { Invitrogen Charge Switch } \\
\text { Kit, } 20 \text { min incub. }\end{array}$ & $\mathrm{n} / \mathrm{a}$ & $10 \mathrm{ng}$ & $\mathrm{n} / \mathrm{a}$ & $\begin{array}{l}\text { Sexing, } \\
10 \text { microsats, } \\
\text { CR }\end{array}$ & Alstad 2010 \\
\hline $\begin{array}{l}\text { DNARelease } 7 \mathrm{~min} \text { incub., } \\
\text { and alkaline lysis } 20 \mathrm{~min} \\
\text { incub. }\end{array}$ & $\mathrm{n} / \mathrm{a}$ & $2 \mu \mathrm{L}$ & $\mathrm{n} / \mathrm{a}$ & Sexing & Brubaker et al. 2011 \\
\hline $\begin{array}{l}\text { DNeasy Tissue kit, overnight } \\
\text { incub. }\end{array}$ & $\begin{array}{l}11.8 \pm 18.1 \mathrm{ng} / \mu \mathrm{L} \\
\quad(1.8-2.4 \mu \mathrm{g})^{\mathrm{a}}\end{array}$ & $\begin{array}{c}3 \mu \mathrm{L} \text { of } \\
0.3-60 \\
\mathrm{ng} / \mu \mathrm{L}\end{array}$ & 100 & Microsats & Yannic et al. 2011 \\
\hline $\begin{array}{l}15 \min 56^{\circ} \mathrm{C} \text { incub., boil } 8 \\
\text { min, spin } 13,000 \times \mathrm{g} 3 \mathrm{~min}\end{array}$ & $\mathrm{n} / \mathrm{a}$ & $11-13 \mu \mathrm{L}$ & $89-91$ & Sexing & Wellbrock et al. 2012 \\
\hline $\begin{array}{l}\text { KAPA Express Extract kit, } \\
20 \text { min incub. }\end{array}$ & $\mathrm{n} / \mathrm{a}$ & $10 \mu \mathrm{L}$ & 100 & Sexing & Bosnjak et al. 2013 \\
\hline $\begin{array}{l}15 \min 56{ }^{\circ} \mathrm{C} \text { incub., boil } 8 \\
\text { min, spin } 15,000 \times \mathrm{g} 3 \mathrm{~min}\end{array}$ & $\mathrm{n} / \mathrm{a}$ & $19 \mu \mathrm{L}$ & 89-100 & Sexing & Adam et al. 2014 \\
\hline
\end{tabular}

then placed in a vial containing $1 \mathrm{~mL}$ Longmire buffer (100 mM Tris-HCl, $100 \mathrm{mM}$ EDTA, $10 \mathrm{mM}$ $\mathrm{NaCl}, 0.5 \%$ sodium dodecyl sulfate [SDS]; Longmire et al. 1992). We chose Longmire buffer because most laboratories already stock this buffer to store blood samples taken in the field. The swabs in buffer were at times stored at ambient temperature in the field for up to 2 weeks before they could be placed in freezers and shipped to our laboratory, where they were kept frozen at $-20{ }^{\circ} \mathrm{C}$ until extraction (up to 16 months post sampling).

\section{DNA extraction and amplification}

The buffer from each sample tube was transferred to a fresh Eppendorf tube, taking care to squeeze out residual buffer retained in the swab against the rim of the tube. We added $40 \mu \mathrm{L}$ of Proteinase K (20 mg/mL, Promega) to each tube and then vortexed and incubated at $56{ }^{\circ} \mathrm{C}$ for $3 \mathrm{~h}$ before incubating at $95{ }^{\circ} \mathrm{C}$ for $5 \mathrm{~min}$ to inactivate any residual proteinase K. Samples were spun through Amicon Ultra $0.5 \mathrm{~mL}$ columns (Millipore), washing 2-3 times with $150 \mu \mathrm{L}$ ultrapure water prior to reversing the column, resulting in $\sim 30-50 \mu \mathrm{L}$ elution volume in ultrapure water. All extraction sessions included a blank control, and all extracts were quantified on a Qubit Fluorometer 2.0 (Invitrogen) using high sensitivity reagents (detection range of 10 to $100 \mathrm{ng} / \mu \mathrm{L}$ ).

Extraction success was based on a positive Qubit DNA quantification reading, where all readings too low to measure $(<10 \mathrm{pg} / \mu \mathrm{L})$ would be considered a failed extraction. Amplification success was calculated as a percentage and determined from presence of and correct band size on a $1 \%$ agarose gel, following amplification with a species-specific primer pair designed to amplify a 100 base pair (bp) section of the mitochondrial control region (NEW_80f: 5'TTCTCCTCCCTCTTGTCAGC'3; new CR1Er: 5'AAGTACATAGGTTAGACATGAATG'3). Buccal swab extracts were amplified in $25 \mu \mathrm{L}$ reactions containing $1 \times$ PCR buffer, $2 \mathrm{mM}$ $\mathrm{MgCl}_{2}, 1 \mathrm{mM}$ mixed dNTPs, $0.04 \mathrm{U}$ Taq Gold, 0.4 $\mathrm{mM}$ of each primer, $0.96 \mathrm{mg} / \mathrm{mL}$ BSA, and $2-3 \mu \mathrm{L}$ DNA extract diluted 1:50-1:120. Polymerace chain reaction (PCR) amplifications were per- 


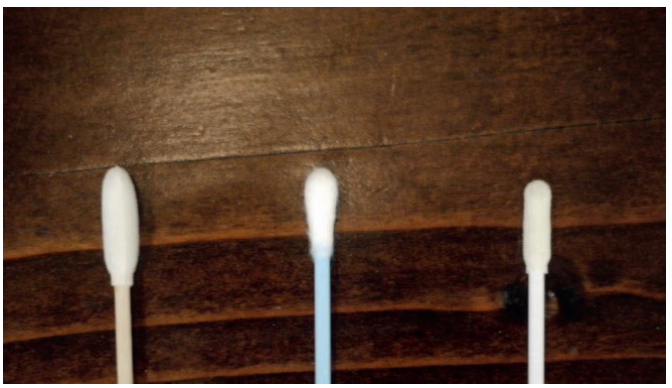

Figure 1. Buccal swab types tested: (1) foam tip on wood handle, (2) cotton tip on plastic handle, and (3) foam tip on plastic handle. Photo by: Julia Vilstrup.

formed using a BIO-RAD Thermocycler with a 5 min activation step at $95{ }^{\circ} \mathrm{C}$, followed by $35-45$ cycles of $95{ }^{\circ} \mathrm{C}$ for $30 \mathrm{~s}, 53.5^{\circ} \mathrm{C}$ for $30 \mathrm{~s}, 72{ }^{\circ} \mathrm{C}$ for $30 \mathrm{~s}$, followed by a final extension period of $72{ }^{\circ} \mathrm{C}$ for 10 min. All PCR sessions included a blank control.

\section{Data analyses}

Average DNA concentrations $(\mathrm{ng} / \mu \mathrm{L})$ and total DNA yield (ng) obtained post extraction from Qubit readings were compared among the 3 swabs types. A 2-way analysis of variance (ANOVA) was performed in $\mathrm{R}$ version 3 (R Core Team 2015) to examine the relationship between DNA quantities and the type of swab used, and between DNA quantities and sampling location. The latter test allowed us to examine the effects of individual field crews on the quantity of DNA obtained using this protocol. The Tukey honest significant difference (HSD) test was also used post hoc to determine if the overall average DNA yield of each swab type was significantly different from the other 2 swabs.

\section{Results}

We had a $100 \%$ extraction success rate among the 72 buccal swabs tested. The buccal swabs yielded on average $4.7 \pm 0.58 \mathrm{ng} / \mu \mathrm{L}$ of DNA, or a total yield of $0.14-0.24 \mu \mathrm{g}$ DNA based on elution volumes of $\sim 30-50 \mu \mathrm{L}$ (Table 2). This yield is substantially less DNA than typically obtained from blood extractions (e.g., Handel et al. 2006); however, the swabs overall, regardless of swab type, provided sufficient quality and quantity DNA for amplification once diluted 1:50-1:120; we

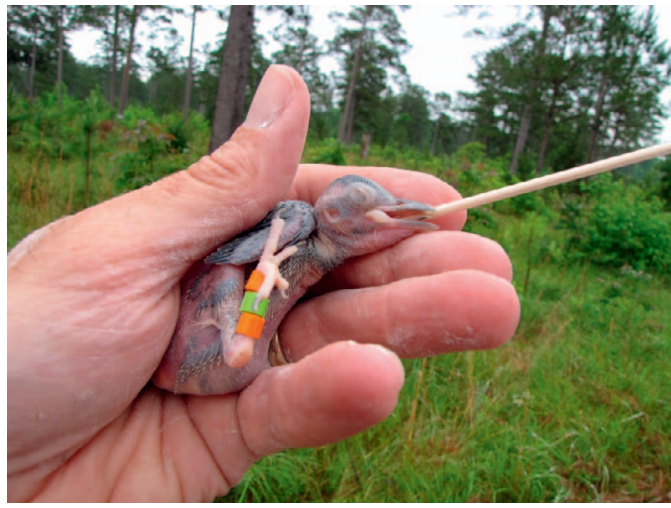

Figure 2. Nestling Red-cockaded Woodpecker being swabbed at Sehoy Plantation, Alabama, with a foam on wood swab. Photo by: Eric Spadgenske.

successfully amplified PCR products from $97.2 \%$ of the samples.

We found a significant relationship between DNA concentration and swab used $(F=13.39$, df $=2, P=0.0000$ ). The foam on wood and foam on plastic swabs performed best, resulting in 4-5 times the amount of DNA compared to the cotton on plastic swabs (Table 2). The cotton on plastic swabs resulted in significantly lower yield than the foam on plastic $(P=0.009)$ and foam on wood swabs $(P=0.0000)$, whereas there was no significant difference in average DNA concentration between the foam on plastic and foam on wood swabs $(P=0.101)$. We also observed a strong correlation between DNA yield and sampling location $(F=26.44$, df $=5, P=0.0000)$, implying a variation in sampling efficiency among field personnel following the same protocol.

\section{Discussion}

Yields from our new protocol indicated that inexpensive generic swabs can collect enough buccal cells in the field to obtain adequate DNA for population genetic studies without $10-15 \mathrm{~min}$ of drying and then freezing in the field. These results will simplify safe collection of hundreds, if not thousands, of samples by technicians with limited experience.

\section{Swab selection}

Cotton swabs are the most common type of commercial swab available, but in our study foam 
Table 2. Red-cockaded Woodpecker DNA extraction success, amplification (amp.) success, concentration (conc.), and yield among 3 buccal swab types (mean [SE]) assuming an elution volume of $40 \mu \mathrm{L}$.

\begin{tabular}{lcccrc}
\hline \multicolumn{1}{c}{ Swab type } & Extraction success & Amp. success $\%$ & DNA conc. (ng/ $\mu \mathrm{L})$ & DNA yield $(\mathrm{ng})$ & DNA conc. range $(\mathrm{ng} / \mu \mathrm{L})$ \\
\hline Cotton on plastic & $24 / 24$ & 100 & $1.35(0.31)^{\mathrm{a}}$ & $54.2(12.3)$ & $0.5-7.6$ \\
Foam on plastic & $24 / 24$ & 91.6 & $5.11(1.25)$ & $204.2(50.1)$ & $0.5-24.4$ \\
Foam on wood & $24 / 24$ & 100 & $7.65(0.76)$ & $306.2(30.6)$ & $3.2-15.4$ \\
Total swabs & $72 / 72$ & 97.2 & $4.70(0.58)$ & $188.2(23.2)$ & $0.5-24.4$ \\
\hline
\end{tabular}

${ }^{a}$ Significantly lower DNA concentration than the two other swab types.

on wood and plastic outperformed cotton swabs, with the larger foam on wood providing the highest DNA yield (Fig. 1). This finding suggests that the material used and the surface area of the swab is crucial to how much saliva and buccal cells will attach to it. The thicker foam tip swab may be more abrasive, providing a particularly effective surface for collecting sample material and as an easier surface to squeeze out the remaining Longmire buffer. For smaller nestlings, larger swab sizes may be logistically difficult to place in their mouths. In these cases, absorbent paper strips have been shown to function well (Wellbrock et al. 2012, Adam et al. 2014). Finally, some field personnel commented that nestlings would bite down on whichever swab was offered closest to the mouth, suggesting swab presentation direction is key for getting the most buccal cells.

We do not believe the handle of the swab (wood or plastic) had any effect on extraction. Others have noted that certain swab handles of treated wood may inhibit DNA extraction and amplification (Burtis et al. 2012). If the swab handles have been treated, storage of the swabs in the buffer post sampling could release inhibitors into the buffer that would subsequently be extracted. We saw no evidence of inhibition caused by swab type in any of our samples, however; initial PCR success was similar across all swab types.

Our best performing swab was half the cost of some commercial swabs (e.g., cotton swabs from Milian Dutscher Group, Switzerland). Commercially available extraction kits and swabs cost US\$5$\$ 11.5$ per sample (e.g., Boca Scientific's Isohelix Buccal DNA Isolation Kit with swabs). Our cost per sample, including Longmire buffer for swab storage, swab, extraction reagents, and Amicon columns, was US\$4-\$4.5 per sample, depending on the swab used, making our protocol an affordable alternative, especially for large population studies.

\section{Field protocols}

Feedback from field personnel was positive. Swabbing took 40-60 s during nestling banding and was easier, less stressful (on bird and technician), and slightly quicker than collecting blood samples from birds. The observed correlation in DNA yield among sampling locations suggests variation among individuals performing the sampling may be expected in a study that employs numerous field personnel. Increased training may partially compensate for this variation (see training video in Guidelines to the Use of Wild Birds in Research; Fair et al. 2010). Even so, the lowest yields were still sufficient for a population genetics study (JTV unpubl.).

Although buccal swabs are easy and efficient to collect, blood sampling will likely remain preferential in many situations, particularly when bigger birds are involved and collecting a blood sample is not difficult but getting a buccal swab out of their mouths might be (e.g., raptors, which may snap the swab). Further, blood samples can be stored for $25+$ years (TDM, pers. obs.) and still yield high quality DNA, making them better suited for archival sampling than buccal swabs (up to 18 months; Handel et al. 2006). Although generally minimal, complications can arise in collecting blood samples from birds, such as collapsing veins, hematomas, and difficulty stopping blood flow (Hoysak and Weatherhead 1991, Brown and Brown 2009). These drawbacks provided us an opportunity, via collaborating with $>50$ field technicians across the range of the Red-cockaded Woodpecker, to collect $>1,800$ buccal swab samples in 2014, a feat we could not have accomplished without a simple sampling protocol.

Our new protocol omits the $10-15$ min swab drying stage of some commercial buccal swab protocols, which potentially led to lower DNA yields, as reported in other studies (Meldgaard et 
al. 2004). Yields reported by many manufacturers possibly represent expected values in clinical settings where samples get processed relatively quickly under controlled conditions. The variable conditions that samples may be exposed to under dynamic field settings and during shipping to the laboratory may further contribute to the reduced yields we observed. Despite lower yields overall in our protocol that excluded the drying stage, our method produced sufficient DNA for multiple loci genetic studies. The resulting reduced time costs of our protocol enabled us to complete an extensive species-wide sampling in one field season that otherwise would not have been possible.

\section{DNA yield}

We had high amplification success, and the DNA provided high-quality sequence data. A simultaneous population study of Red-cockaded Woodpeckers using buccal swabs is in progress. The microsatellite portion of this study using 9 microsatellite markers gave no indication of allelic dropout (JTV, unpubl.). Normal precautions to minimize allelic dropout or other problems associated with low DNA concentrations should be considered when amplifying microsatellites by employing duplicates and estimating null alleles (Bonin et al. 2004). Further, buccal swabs likely cannot provide sufficient material for high throughput genomic studies, which typically may require $\sim 1-5 \mu$ g of DNA for many protocols (e.g., Illumina paired-end library).

Comparing our results with other studies using buccal swabs is difficult because more than half do not mention their resulting DNA concentrations or yield. Instead they only specify the volume of DNA extract or DNA quantity used for PCR (Table 1). Nevertheless, our DNA yields were lower compared to reports from similar studies using buccal swabs (Table 1), claims on commercial swab kits, and typical yields from blood extractions. Fortunately, with improved molecular techniques, working with trace amounts of DNA has become much more feasible (Van Oorschot et al. 2010), enabling buccal swabs to be an ideal candidate for population genetic sampling.

Higher DNA yields might be possible or more similar to those of Bush et al. (2005) and Yannic et al. (2011) if field crews have 10-15 min available to dry each sample prior to storage in Longmire buffer. Air-drying the swabs is also recommended for longer-term storage when extraction is not performed shortly after collection (Jetquick protocol for the purification of DNA from buccal swabs; www.brunschwig-ch.com). Seki (2003) also stored cotton swabs in a storage buffer, resulting in DNA yields an order of magnitude greater than ours (1,300 vs. $188 \mathrm{ng})$. Their extraction method incorporated an incubation period $14 \mathrm{~h}$ longer than ours and may have increased the resulting yield; therefore, the role of storage in Longmire buffer is unclear in relation to DNA yield compared to dry storage or storage in ethanol. The most ideal storage buffer may differ depending on tissue type (Camacho-Sanchez et al. 2013).

\section{Laboratory protocols}

We informally tested a few additional DNA extraction protocols for this investigation, including the QIAamp DNA Micro kit (QIAGEN), which needed to incubate overnight (vs. $3 \mathrm{~h}$ ) to obtain similar yields and had a slightly higher cost per sample. We also tested a modified forensic extraction protocol (Allen et al. 1998) that resulted in lower yields than those we achieved (results not shown). Ultimately, we chose Amicon columns for purification and concentration of our extracts because of our familiarity with the product and prior successes when dealing with trace DNA samples. Nonetheless, any purification method (e.g., ethanol, isopropanol precipitation, or Qiagen columns) would probably provide reasonable results, and we therefore suggest that individual laboratories adapt the protocol to include their preferred DNA purification technique. Note that we had some inhibition in some of our extracts, which required us to dilute our extracts at least 1:50 for positive amplification; however, our amplification success of $97.2 \%$ was similar to other studies (Table 1). This PCR inhibition may have been an artifact of the purification method used but did not correlate to the type of swab.

\section{Conclusions}

We developed and tested a time- and costeffective, field-friendly protocol that employs inexpensive generic swabs in conjunction with direct buccal sample storage in Longmire buffer without involving prior air-drying of the swab. 
Using a simple DNA extraction protocol, we showed that generic foam-tipped and cotton-tipped buccal swabs can provide ample DNA to serve as the basis for population genetic and other investigations while minimizing the degree of trauma experienced by individual animals. Our buccal swab sampling protocol results in more time- and cost-effective field sampling of small individuals, juveniles, and/or species in which obtaining other tissue types would be difficult. This economic approach further increases the potential range and number of samples collected because relatively inexperienced field staff can collect buccal swabs without fear of harming individuals. Finally, we call on other field users of buccal swabs to report details of their results including swab type used, DNA concentrations, and yields to further develop this useful technique.

\section{Acknowledgments}

We are grateful to the many biologists who swabbed nestlings for us throughout the range of the Red-cockaded Woodpecker: A. Alost, M. Caylor, J. Engle, T. Grazia, R. Hasken, B. Kohls, S. Lauerman, B. Meriwether, R. Mullins, L. Ramirez, S. Shively, E. Smith, S. Steele, J. Stober, R. Eastridge, G. Hanks, N. Jordan, M. Keys, C. Legleu, S. Lewis, E. Spadgenske, M. Dowdell, N. Dwyer, A. van Lanen, P. Miles, R. Scott, S. Shattler, V. Sparling, L. Langston, C. Pedersen, V. Morris, D. Work, J. Cox, T. Engstrom, E. Baka, F. Burks, J. Skeen, E. Angell, L. Blanc, S. Goodman, M. Barron, K. Brust, J. Schillaci, S. Camp, N. Hawkins, J. Fryar, K. Moore, M. Wilcox, L. Carlile, J. Perkins, H. Collins, J. Hovis, R. Garrison, J. Goodson, A. Jackson, M. Folk, J. McGlincy, B. Holimon, L. Wood, J. Casto, B. Clontz, B. Rutledge, and R. Carrie. We also thank J. Thompson and C. Mulch for laboratory assistance. We appreciate the comments on the manuscript by C. Phillips and 2 anonymous reviewers. This study was funded by a postdoctoral research grant (VKR023371) from the Villum Foundation (JTV) and the USGS Forest and Rangeland Ecosystem Science Center. Any use of trade, product, or firm names is for descriptive purposes only and does not imply endorsement by the US Government.

\section{Literature cited}

Adam I, Scharff C, Honarmand M. 2014. Who is who? Non-invasive methods to individually sex and mark altricial chicks. Journal of Visualized Experiments. 87:e51429.

Allen M, Engstrom A-S, Meyers S, Handt O, Saldeen T, et al. 1998. Mitochondrial DNA sequencing of shed hairs and saliva on robbery caps: sensitivity and matching probabilities. Journal of Forensic Sciences. 43:453464.
Arima H, Ohnishi N. 2006. Usefulness of avian buccal cells for molecular sexing. Ornithological Science. 5:139143.

Beebee TJC. 2007. Buccal swabbing as a source of DNA from squamate reptiles. Conservation Genetics. 9:1087-1088.

Bonin A, Bellemain E, Bronken Eidensen P, Pompanon F, Brochmann C, Taberlet P. 2004. How to track and assess genotyping errors in population genetics studies. Molecular Ecology. 13:3261-3273.

Bosnjak J, Stevanov-Pavlovic M, Vucicevic M, Stevanovic J, Simeunovic P, et al. 2013. Feasibility of non-invasive molecular method for sexing parrots. Pakistan Journal of Zoology. 45:715-720.

Broquet T, Berset-Braendli L, Emaresi G, Fumagalli L. 2006. Buccal swabs allow efficient and reliable microsatellite genotyping in amphibians. Conservation Genetics. 8:509-511.

Brown MB, Brown CR. 2009. Blood sampling reduces annual survival in Cliff Swallows (Petrochelidon pyrrhonota). Auk. 126:853-861.

Brubaker JL Karouna-Renier NK, Chen Y, Jenko K Sprague DT, Henry PFP. 2011. A noninvasive, direct real-time PCR method for sex determination in multiple avian species. Molecular Ecology Resources. 11:415-417.

Burtis CA, Ashwood ER, Bruns DE. 2012. Tietz textbook of clinical chemistry and molecular diagnostics. Elsevier Health Sciences; $158 \mathrm{p}$.

Bush KL, Vinsky MD, Aldridge CL, Paszkowski CA. 2005. A comparison of sample types varying in invasiveness for use in DNA sex determination in an endangered population of greater Sage-Grouse (Centrocercus uropihasianus). Conservation Genetics. 6:867-870.

Camacho-Sanchez M, Burraco P, Gomez-Mestre I, Leonard JA. 2013. Preservation of RNA and DNA from mammal species under field conditions. Molecular Ecology Resources. 13:663-673.

Campanella JJ, Smalley JV. 2006. A minimally invasive method of piscine tissue collection and an analysis of long-term field-storage conditions for samples. BMC Genetics. 7:32.

Dai Y, Lin Q, Fang W, Zhou X, Chen X. 2015. Noninvasive and nondestructive sampling for avian microsatellite genotyping: a case study on the vulnerable Chinese Egret (Egretta eulophotes). Avian Research. 6:24.

De Volo SB, Reynolds RT, Douglas MR, Antolin MF. 2008. An improved extraction method to increase DNA yield from molted feathers. Condor. 110:762-766.

Fair J, Paul E, Jones J. 2010. Guidelines to the use of wild birds in research. Washington (DC): Ornithological Council.

Funk WC, Mullins TD, Haig SM. 2007. Conservation genetics of Snowy Plovers (Charadrius alexandrinus) in the Western Hemisphere: population genetic structure and delineation of subspecies. Conservation Genetics. 8:1287-1309.

Garza JC, Woodruff DS. 1992. A phylogenetic study of the gibbons (Hylobates) using DNA obtained noninvasively from hair. Molecular Phylogenetics and Evolution. 1:202-210. 
Gerloff U, Schlötterer C, Rassmann K, Rambold I, Hohmann G, et al. 1995. Amplification of hypervariable simple sequence repeats (microsatellites) from excremental DNA of wild living bonobos (Pan paniscus). Molecular Ecology. 4:515-518.

Haig SM, Miller MP, Bellinger MR, Draheim HM, Mercer DM, Mullins TD. 2016. The conservation genetics juggling act: integrating genetics and ecology, science and policy. Evolutionary Applications. 9:181-195.

Haig SM, Rhymer JM, Heckel DG. 1994. Population differentiation in randomly amplified polymorphic DNA of Red-cockaded Woodpeckers Picoides borealis. Molecular Ecology. 3:581-595.

Handel CM, Pajot LM, Talbot SL, Sage GK. 2006. Use of buccal swabs for sampling DNA from nestling and adult birds. Wildlife Society Bulletin. 34:1094-1100.

Harvey MG, Bonter DN, Stenzler LM, Lovette IJ. 2006. A comparison of plucked feathers versus blood samples as DNA sources for molecular sexing. Journal of Field Ornithology. 77:136-140.

Hoysak DJ, Weatherhead PJ. 1991. Sampling blood from birds: a technique and an assessment of its effect. Condor. 93:746-752.

Idaghdour Y, Broderick D, Korrida A. 2003. Faeces as a source of DNA for molecular studies in a threatened population of Great Bustards. Conservation Genetics. 4:789-792.

Longmire JL, Gee GF, Hardekopf CL, Mark GA. 1992. Establishing paternity in Whooping Cranes (Grus americanus) by DNA analysis. Auk. 109:522-529.

Meldgaard M, Bollen PJA, Finsen B. 2004. Non-invasive method for sampling and extraction of mouse DNA for PCR. Laboratory Animals. 38:413-417.

Miller HC. 2006. Cloacal and buccal swabs are a reliable source of DNA for microsatellite genotyping of reptiles. Conservation Genetics. 7:1001-1003.

Müllenbach R, Lagoda PJ, Welter C. 1989. An efficient saltchloroform extraction of DNA from blood and tissues. Trends in Genetics. 5:391.

Pidancier N, Miquel C, Miaus C. 2003. Buccal swabs as a non-destructive tissue sampling method for DNA analysis in amphibians. Herpetological Journal. 13:175-178.

Poschadel JR, Moller D. 2004. A versatile field method for tissue sampling on small reptiles and amphibians, applied to pond turtles, newts, frogs and toads. Conservation Genetics. 5:865-867.

R Core Team. 2015. R: a language and environment for statistical computing. R Foundation for Statistical Computing, Vienna (Austria). https://www.R-project. org/
Romain-Bondi KA, Wielgus RB, Waits L, Kasworm WF, Austin M, Wakkinen W. 2004. Density and population size estimates for North Cascade grizzly bears using DNA hair-sampling techniques. Biological Conservation. 117:417-428.

Rudnick JA, Katzner TE, Bragin EA, DeWoody JA. 2008. A non-invasive genetic evaluation of population size, natal philopatry, and roosting behavior of non-breeding eastern imperial eagles (Aquila heliaca) in central Asia. Conservation Genetics. 9:667-676.

Seki S-I. 2003. Molecular sexing of individual Ryukyu Robins Erithacus komadori using buccal cells as a noninvasive source of DNA. Ornithological Science. $2: 135-137$

Smalley JV, Campanella JJ. 2005. Buccal swabbing and extraction of high quality sunfish (Lepomis) DNA for use in PCR analysis. Biotechniques. 38:188-192.

Steinberg KK, Sanderlin KC, Ou Cy, Hannon WH, McQuillan GM, Sampson EJ. 1997. DNA banking in epidemiologic studies. Epidemiologic Reviews. 19:156-162.

Taberlet P, Bouvet J. 1991. A single plucked feather as a source of DNA for bird genetic studies. Auk. 108:959960.

[USFW] US Fish and Wildlife Service. 2003. Red-cockaded Woodpecker (Picoides borealis) recovery plan: Second revision. Atlanta (GA).

Van Oorschot RAH, Ballantyne KN, Mitchell RJ. 2010. Forensic trace DNA: a review. Investigative Genetics. $1: 14$.

Walker AH, Najarian D, White DL, Jaffe JF, Kanetsky PA, Rebbeck TR. 1999. Collection of genomic DNA by buccal swabs for polymerase chain reaction-based biomarker assays. Environmental Health Perspectives. 107:517.

Walters JR, Garcia V. 2016. Red-cockaded Woodpeckers: Alternative pathways to breeding success. In: Koenig WD, Dickinson JL, editors. Cooperative breeding in vertebrates: studies of ecology, evolution, and behavior. London (UK): Cambridge University Press.

Wellbrock AHKJ, Bauch C, Rozman J, Witte K. 2012. Buccal swabs as a reliable source of DNA for sexing young and adult Common Swifts (Apus apus). Journal of Ornithology. 153:991-994.

Yannic G, Sermier R, Aebischer A, Gavrilo MV, Gilg O, et al. 2011. Description of microsatellite markers and genotyping performance using feathers and buccal swabs for the Ivory Gull (Pagophila eburnean). Molecular Ecology Resources. 11:877-889. 